\title{
Clinicopathological study of puerperal sepsis including microbiological profile: at a tertiary health care centre
}

\author{
Karthik Chandra Bassetty ${ }^{1 *}$, Rina Dutta Ahmed ${ }^{1}$, Lahari Saikia ${ }^{2}$
}

\begin{abstract}
${ }^{1}$ Department of Obstetrics and Gynecology, ${ }^{2}$ Department of Microbiology, Assam Medical College and Hospital, Dibrugarh, Assam, India
\end{abstract}

Received: 01 June 2018

Accepted: 28 June 2018

\author{
*Correspondence: \\ Dr. Karthik Bassetty, \\ E-mail: kcbassetty@gmail.com
}

Copyright: () the author(s), publisher and licensee Medip Academy. This is an open-access article distributed under the terms of the Creative Commons Attribution Non-Commercial License, which permits unrestricted non-commercial use, distribution, and reproduction in any medium, provided the original work is properly cited.

\begin{abstract}
Background: Puerperal sepsis in developing countries is a major health problem. Antenatal and labour related risk factors play a huge role in causing puerperal sepsis, many of which are modifiable. The aim of the present study is to study the risk factors, clinical features and outcomes of puerperal sepsis in the mother and determine the causative microorganisms involved.

Methods: A prospective observational study was conducted at the department of Obstetrics and Gynaecology, Assam Medical college and Hospital from 1st July 2016 to 30th June 2017.Peurperal sepsis cases were identified based on the WHO clinical definition. A total of 88 patients were identified. Information regarding occupation, antenatal care, delivery related events and outcome were recorded on a predesigned proforma. Mothers were followed up till discharge from the hospital.

Results: Out of 88 clinically diagnosed patients with puerperal sepsis, common risk factors associated with mortality were young age $(\mathrm{p}<0.001)$,primiparity $(\mathrm{p}$ 0.005), tea garden workers( $\mathrm{p} 0.014)$, few antenatal check-ups and unbooked status (p 0.001) inadequate iron prophylaxis .Among labor related events intrauterine fetal demise (p 0.001), absent membranes on admission (0.001), late presentation ( $p$ 0.001) delivery by untrained birth attendant $(\mathrm{p}<0.001)$ were significant.24 patients expired due to the disease. Most common isolated in high vaginal swab and blood culture were Klebsiella pneumoniae and CONS respectively.

Conclusions: Proper antenatal care and institutional deliveries are the prime and only preventive measure to reduce the burden of puerperal sepsis in our setup.
\end{abstract}

Keywords: Microorganisms, Outcomes, Peurperal sepsis, Risk factors, Tertiary institute

\section{INTRODUCTION}

Motherhood is a distinct bio-psychosocial process that transforms and broadens the role of a woman into that of a mother. Peurperium is a period, where the experiences are intense physical and emotional stress due to exhaustion, anxiety and excitement.

In the oldest Japanese classic tale, Kojiki, the goddess Izanami no Mikoto, one of the creators of Japan, was killed by her last son, Kagutsuchi, a deity of fire who burned his mother's birth canal. It is proposed that this tale reflects the incidence of local puerperal infection and subsequent sepsis, the greatest health risk to mothers in ancient Japan. ${ }^{1}$ Hippocratic writings contain references to childbed fever, as do some Hindu texts dating back to 1500 BC. Moreover the potential for birth attendants to initiate such infections seemed evident in some of the ancient writings, including those by the Greek physician Soranus and the Hindus as advice was offered on hygiene for the birth attendants. ${ }^{2-4}$ It is responsible for approximately $10 \%$ of maternal deaths in Africa and 
Asia. ${ }^{5,6}$ According to reports of WHO, puerperal sepsis has been stated to be the second leading cause of maternal mortality in developing countries. ${ }^{7}$

With the above background the present study was carried out with a dedicated approach to find out the risk factors, clinical features and outcomes for puerperal sepsis and also to determine the exact pathogenic organisms with their antibiotic susceptibility in the Department of Obstetrics and Gynaecology in Assam Medical College and Hospital, Dibrugarh.

\section{METHODS}

The prospective observational study was carried out at Assam Medical College and Hospital, Dibrugarh with the following aims and objectives:

- To study the risk factors, clinical features and outcomes of puerperal sepsis in the mother.

- To identify the pathological microorganisms of puerperal sepsis and their sensitivity to antimicrobials.

The study was carried out in the Department of Obstetrics and Gynecology, Assam Medical College and Hospital, Dibrugarh, during the period commencing from 1st July 2016 to 30th June 2017.

A total of 88 patients were identified to have peurperal sepsis as per the WHO working definition. The inclusion criteria included all women presenting to the Department of Obstetrics and Gynaecology AMCH, for the concerned study period for labour and related issues and meeting the WHO criteria for the puerperal sepsis.

\section{WHO case definition of Peurperal Sepsis}

Infection of the genital tract occurring at any time between the rupture of membranes or labour and 42 days postpartum in which fever and one or more of the following are present ${ }^{8}$ :

- Pelvic Pain.

- Abnormal vaginal discharge e.g. presence of pus

- Abnormal smell/foul odour of discharge

- Delay in the rate of reduction of size of the uterus $(<2 \mathrm{~cm} /$ day during the first 8 days)

\section{Exclusion criteria}

- Pre-existing infection prior to labour or rupture of membranes.

- Malaria and typhoid fever.

- Pyrexia due to causes other than due to genital tract sepsis or birth process

- Any major medical illness.
Formats for case taking were made accordingly to facilitate accurate evaluations, interpretations and observations from the study.

After the cervical swab/high vaginal swab was taken, empirical antibiotics were then administered. Once the culture reports are available the antibiotics were changed accordingly. Blood cultures were taken as and only when deemed necessary. Wound swab was taken in infected wounds.

\section{RESULTS}

A total of 88 patients were selected based on the WHO criteria for puerperal sepsis. Majority of the women were of the 20-25 years age group and were primigravidae as shown in Figure 1 and 2. Tea Garden workers accounted for $78.4 \%$ of the patients.

As seen in the antenatal characteristics shown in Fig 3, 24 women were unbooked and 39 women did not have the basic 2 doses of TT immunisations.88\% of women did not have the mandatory 100 tablets of iron and folic acid supplements in pregnancy. Foul smelling discharge was the most common symptom in these women, $26 \%$ of women were delivered by untrained birth attendant as shown in Figure 9.

Mortality was seen in 24 women. Klebsiella pneumonia and CONS and Enterococcus were the most common organism isolated on high vaginal swab and blood culture respectively as shown in figure 11 and 13. It was observed from the Figure 1, the highest number of cases were noted in the 20-25 years of age group (60.23\%) followed by $<20$ years of age group $(28.41 \%)$.

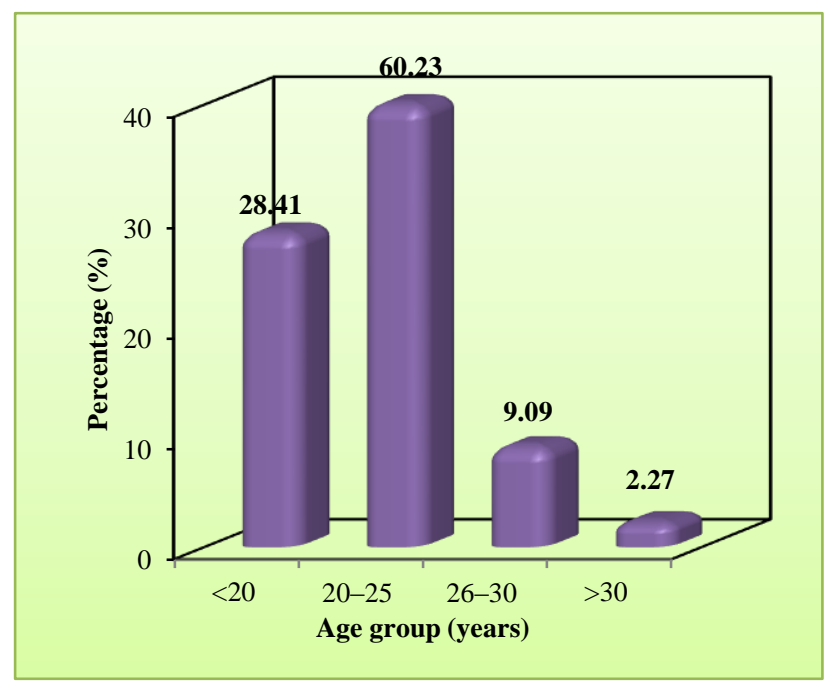

Figure 1: Age distribution of various patients in the study

Primigravidae accounted for $75 \%$ of cases whereas multigravida accounted for the remaining $25 \%$ of cases as shown in Figure 2. 


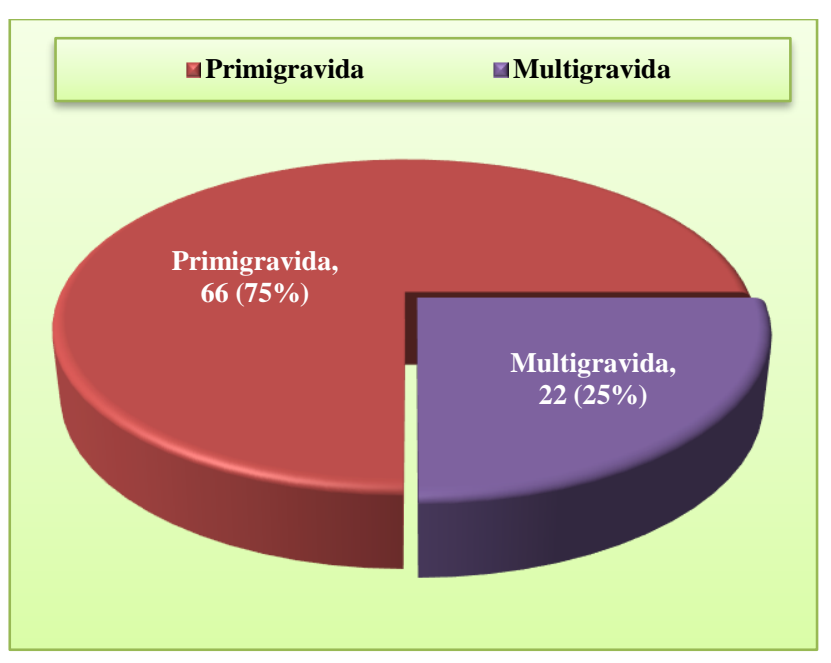

Figure 2: Primiparity and multiparity based classification of the patients.

In the study a total of 64 cases $(72.73 \%)$ were booked cases i.e. had the basic recommended 4 antenatal visits. 24 cases had fewer than four antenatal visits with 7 cases (7\%) having no antenatal checkup of any sort.39 cases had not taken the recommended 2 antenatal TT toxoid doses.88\% of the cases (78) did not taken the recommended iron supplements as shown in the Figure 3.

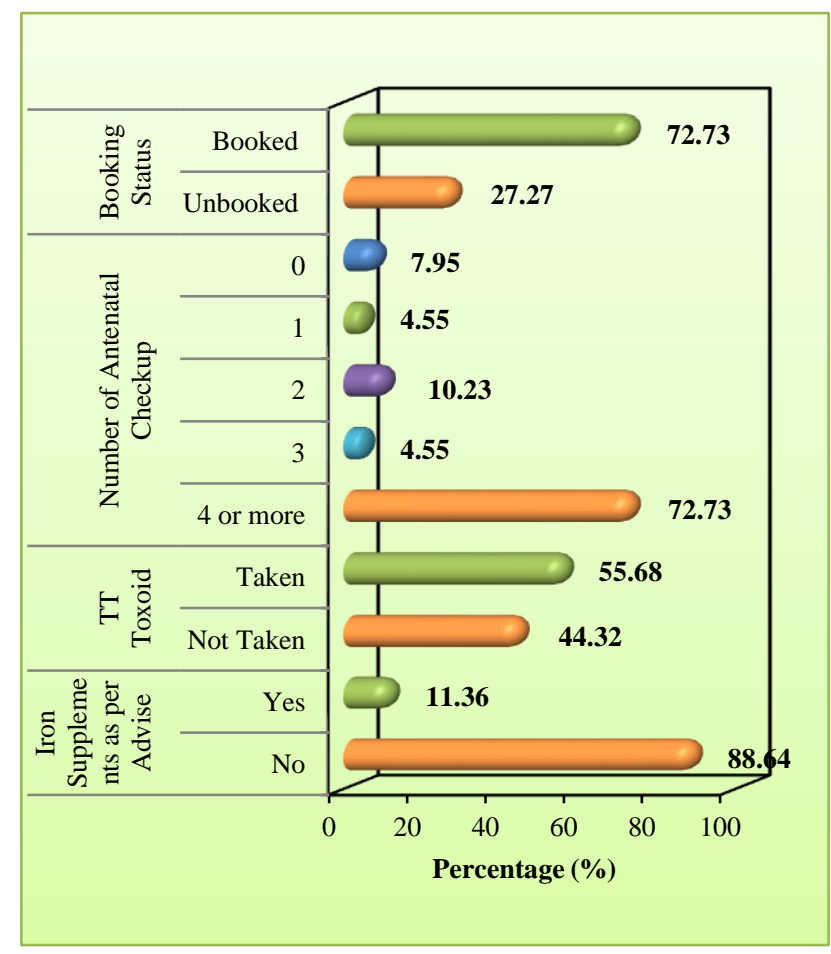

Figure 3: Antenatal characteristics of the various patients.

Tea Garden workers accounted for the majority of the cases $(78.41 \%) .13$ cases were found to be home makers as shown in Figure 4.

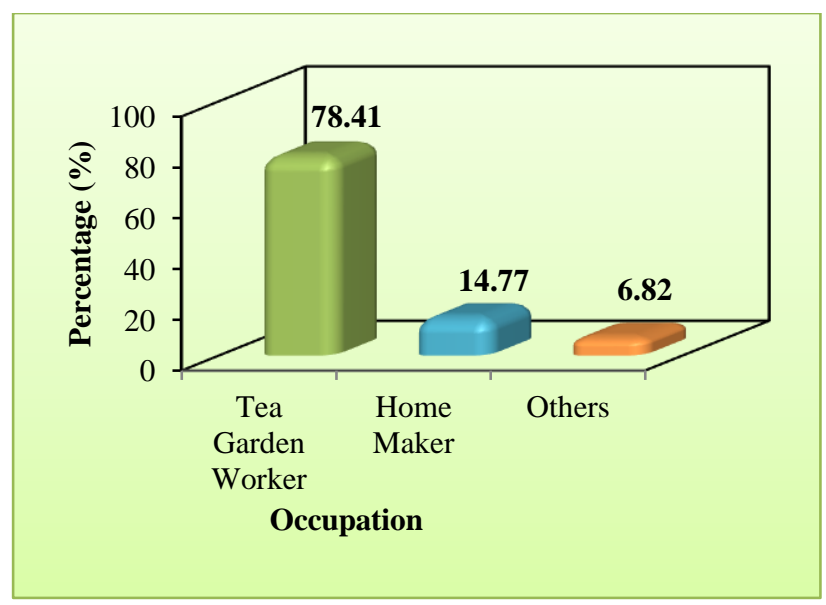

It was observed in the study that the most common symptom of presentation was foul smelling discharge accounting for 71 cases $(80.68 \%)$ followed by swelling of feet $(65.91 \%)$, fever $(68 \%)$, lower abdominal pain $(44.32 \%)$ and dyspnea $(28.41 \%)$ as shown in Figure 5.

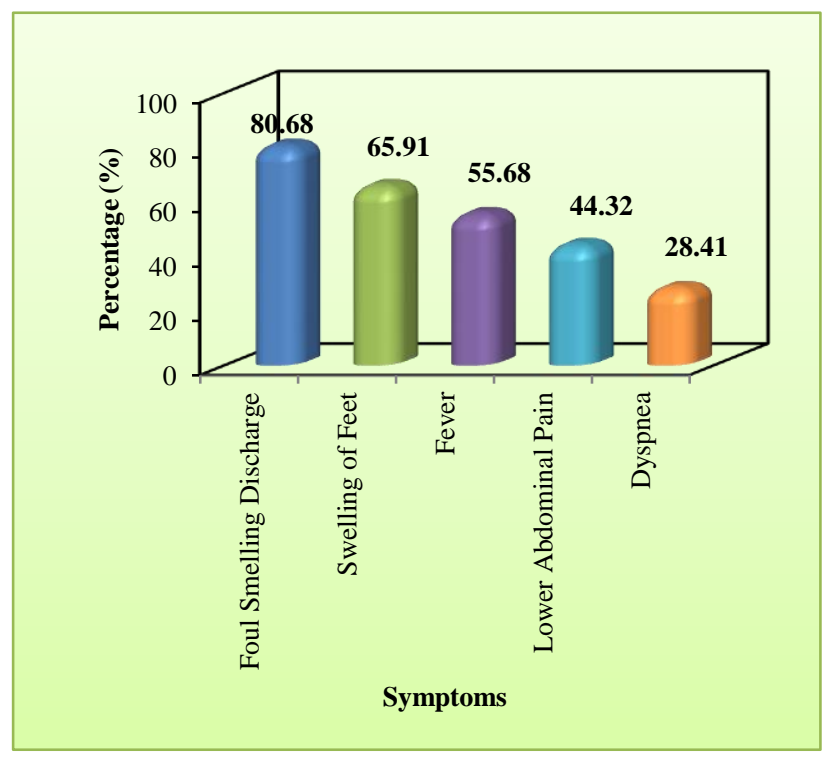

As shown in Figure 6 on examination odema was seen in 76 cases $(86.36 \%)$. Foul smelling discharge and anemia were also commonly seen 80 and $79 \%$ of cases respectively. Least common noted was subinvolution of uterus as seen in 17 cases. Hypertension were noted in $22.73 \%$ of cases. In the study most of the patients (79\%) presented early on day 1 of the illness. 11 patients $(12.5 \%)$ presented late on or after day 3 of the illness as shown in Figure 7.

As shown in Figure 855 cases were associated with a prolonged hospital stay of 7 days or more. As seen in the study labor was induced in 9 cases (10\%). Membranes were intact in 54 cases whereas membranes were absent in 32 cases. Intrauterine fetal death was seen in 32 cases $(36.36 \%)$. Vaginal and caesarean section accounted for 46 cases and 41 cases respectively. 27 cases delivered at home and were delivered by a family member in 23 cases 
and by a trained birth attendant in 4 cases as shown in Figure 9.

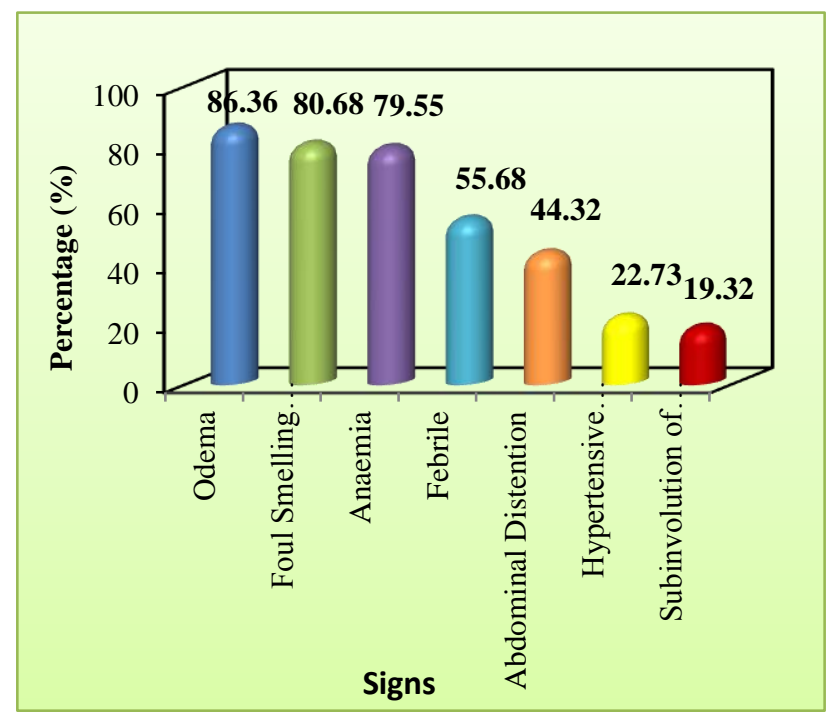

Figure 6: The various signs observed in various patients.

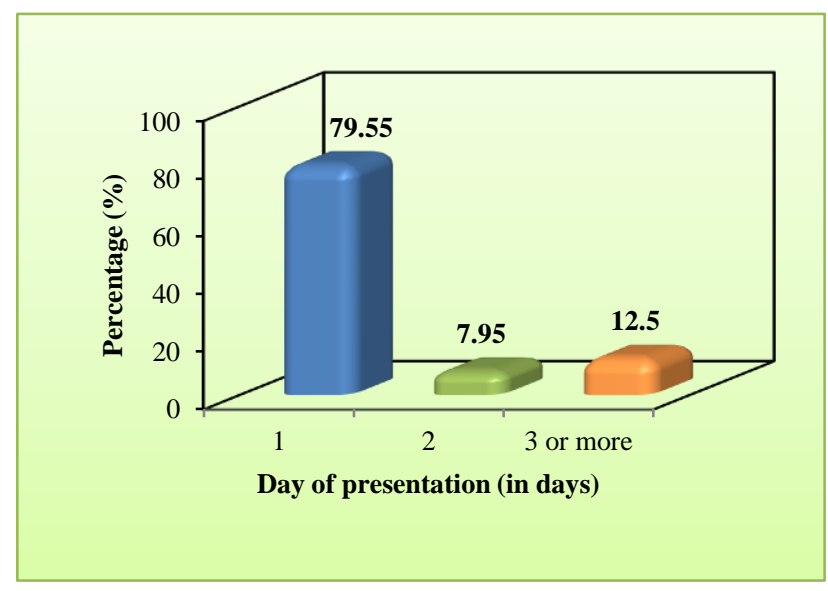

Figure 7: Day of presentation of various patients.

As shown in Figure 10, 24 cases had expired in total (27\% of cases).72\% of cases (64 cases) successfully recovered. In the study Kleibsiella pneumoniaee was the most common organism isolated in high vaginal swab i.e. in $22.73 \%$ of cases followed by CONS in 14 cases $(15.91 \%)$. No organisms were seen in 32 cases $(36.36 \%)$ as shown in Figure 11.

Septicemia was the most common cause of death (21 cases), acute kidney injury, anemia and cardiac failure accounted for the deaths in one case each as shown in Figure 12. However, in blood culture reports CONS was most commonly seen in $17.05 \%$ of cases followed by Enterococcus in $15.91 \%$ of cases. A sterile blood culture report was observed in 56 cases as shown in Figure 13.

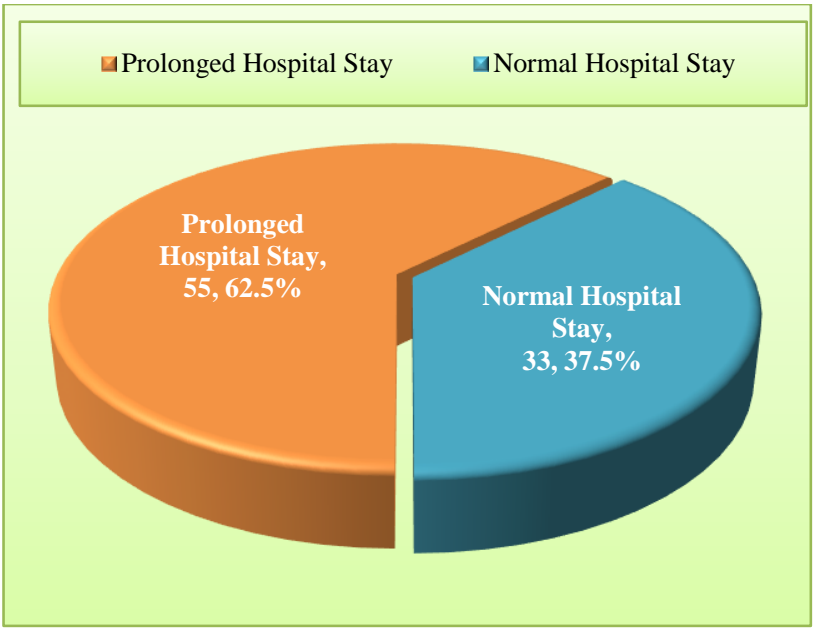

Figure 8: Proportion of patients having a prolonged hospital stay beyond 8 days.

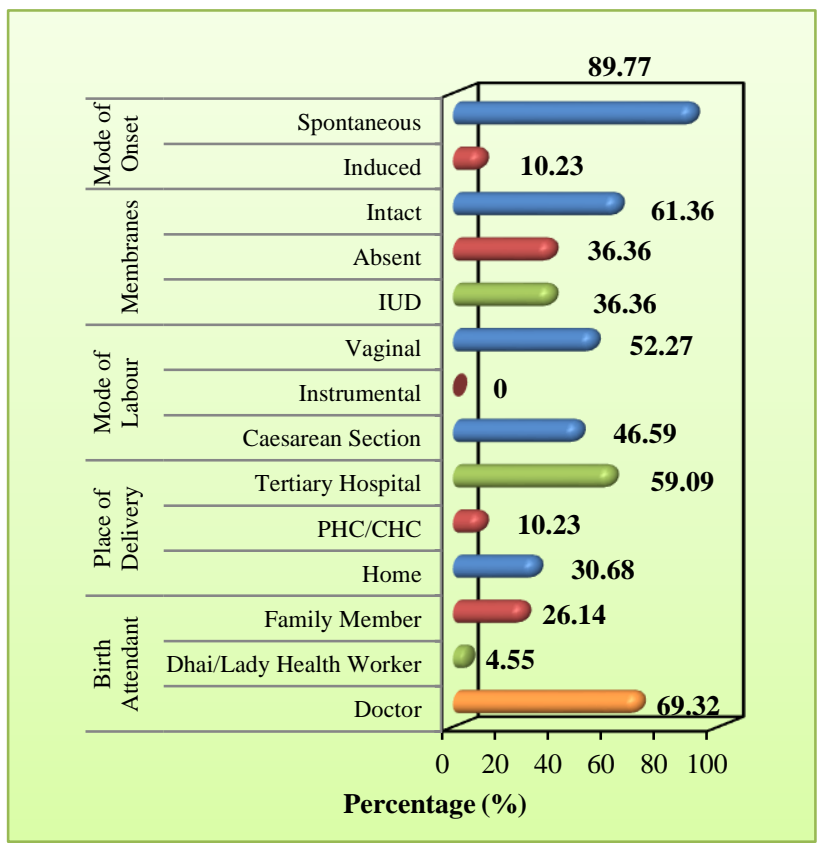

Figure 9: Figure showing the various characteristics of the labor events of the patients.

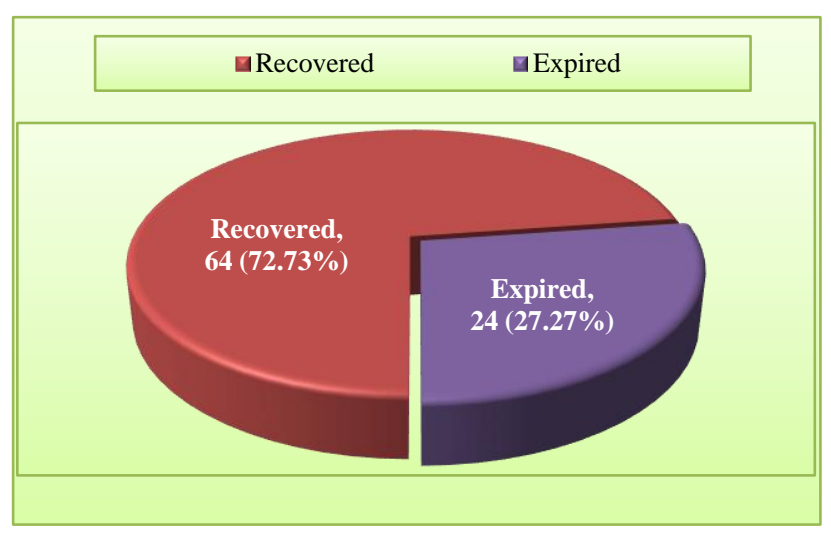

Figure 10: Figure showing outcome of the patients with respect to mortality 


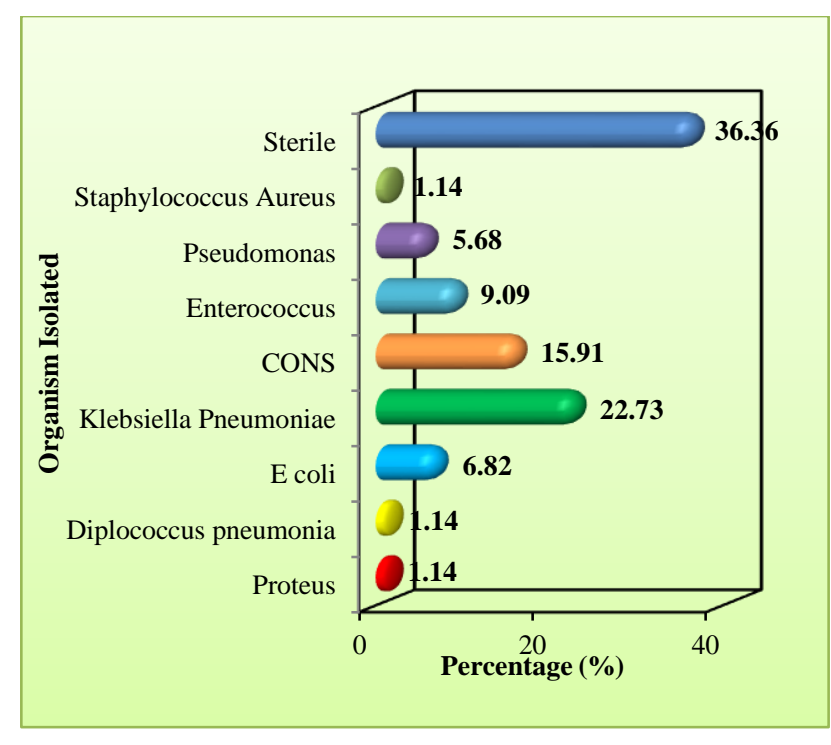

Figure 11- Figure showing organisms isolated in the high vaginal swab.

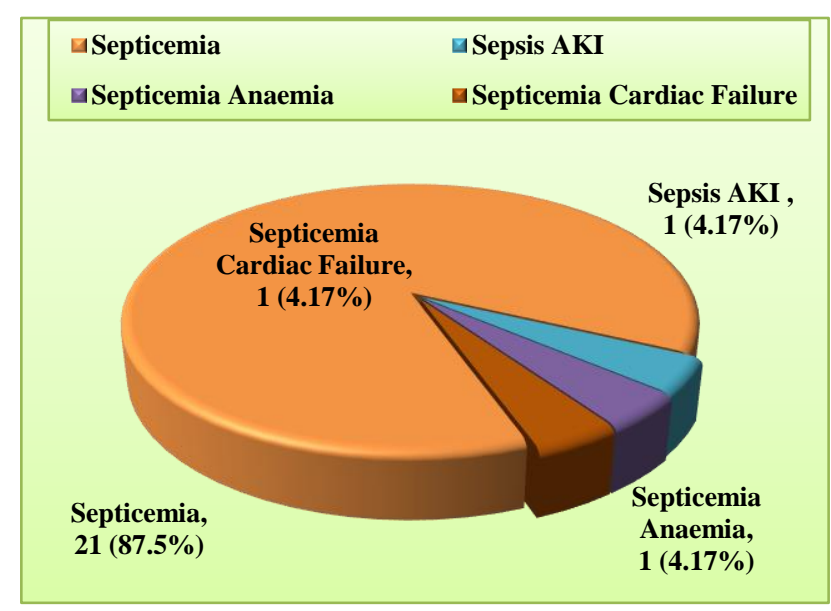

Figure 12: Cause of death

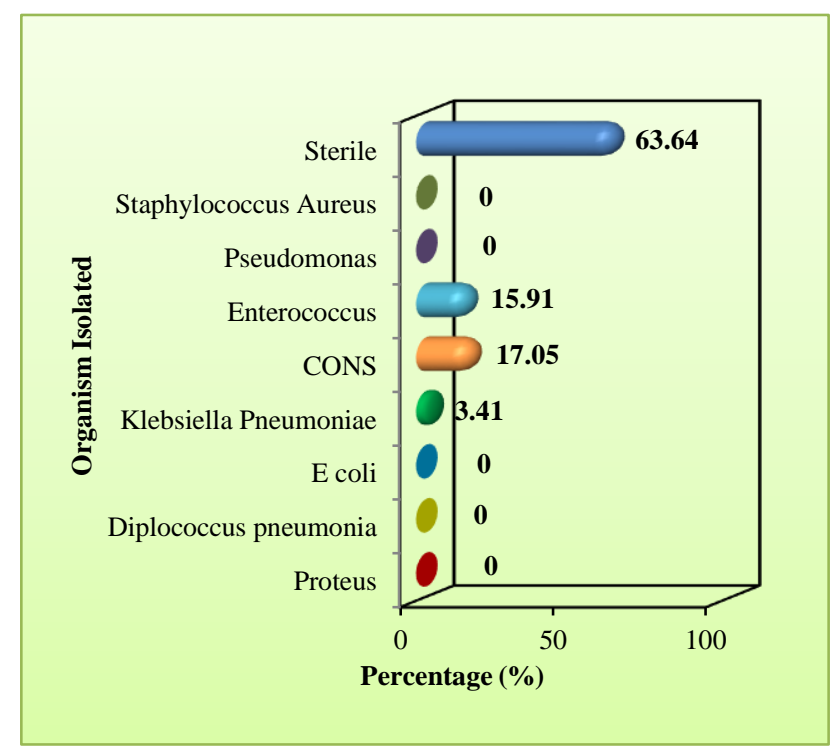

Figure 13: Organism isolated in blood culture

\section{DISCUSSION}

Majority of the patients belonged to the age group of 2025 years. Teenage pregnancies accounted for $28.41 \%$ of total number of cases. This was also seen in recent studies done by Fernandez, Madhudas C, Al-Ostad, Rocca et al, Khaskheli MN, Bauer ME, Shamshad (66\% in age group of 15-25 years), Tamboli et al.,9-15 This reflects an early age of marriage in the Indian subcontinent. Most of these patients are unbooked with no prior antenatal supervision, having delivered at home or in outside hospitals hailing from low socioeconomic status.

Table 1: Test of significance of various factors involved in puerperal sepsis

\begin{tabular}{|c|c|c|}
\hline Variables & P value & Significance \\
\hline Age $<20$ years & $<0.001$ & $\begin{array}{l}\text { Extremely } \\
\text { statistically } \\
\text { significant }\end{array}$ \\
\hline Primiparity & 0.005 & $\begin{array}{l}\text { Statistically } \\
\text { significant }\end{array}$ \\
\hline Tea garden workers & 0.014 & $\begin{array}{l}\text { Statistically } \\
\text { significant }\end{array}$ \\
\hline Unbooked cases & 0.001 & $\begin{array}{l}\text { Extremely } \\
\text { statistically } \\
\text { significant }\end{array}$ \\
\hline $\begin{array}{l}<4 \text { antenatal check- } \\
\text { ups }\end{array}$ & 0.001 & $\begin{array}{l}\text { Extremely } \\
\text { statistically } \\
\text { significant }\end{array}$ \\
\hline $\begin{array}{l}\text { Tetanus toxoid not } \\
\text { taken }\end{array}$ & 0.001 & $\begin{array}{l}\text { Extremely } \\
\text { statistically } \\
\text { significant }\end{array}$ \\
\hline $\begin{array}{l}\text { Iron supplements not } \\
\text { taken }\end{array}$ & 0.14 & Not significant \\
\hline Late presentation & 0.001 & $\begin{array}{l}\text { Extremely } \\
\text { statistically } \\
\text { significant }\end{array}$ \\
\hline Induced labor & 0.25 & Not significant \\
\hline Absent membranes & 0.001 & $\begin{array}{l}\text { Extremely } \\
\text { statistically } \\
\text { significant }\end{array}$ \\
\hline $\begin{array}{l}\text { Intrauterine fetal } \\
\text { demise }\end{array}$ & 0.001 & $\begin{array}{l}\text { Extremely } \\
\text { statistically } \\
\text { significant }\end{array}$ \\
\hline Caesarean delivery & $<0.05$ & $\begin{array}{l}\text { Not quite } \\
\text { statistically } \\
\text { significant }\end{array}$ \\
\hline Home delivery & $<0.05$ & $\begin{array}{l}\text { Not quite } \\
\text { statistically } \\
\text { significant }\end{array}$ \\
\hline $\begin{array}{l}\text { Untrained birth } \\
\text { attendant }\end{array}$ & $<0.001$ & $\begin{array}{l}\text { Extremely } \\
\text { statistically } \\
\text { significant }\end{array}$ \\
\hline $\begin{array}{l}\text { Organism isolated on } \\
\text { High vaginal swab }\end{array}$ & 0.008 & $\begin{array}{l}\text { Extremely } \\
\text { statistically } \\
\text { significant }\end{array}$ \\
\hline $\begin{array}{l}\text { Organism isolated on } \\
\text { blood culture }\end{array}$ & 0.008 & $\begin{array}{l}\text { Extremely } \\
\text { statistically } \\
\text { significant }\end{array}$ \\
\hline
\end{tabular}


Primigravidae accounted for $75 \%$ of cases with multigravidae accounting for $25 \%$ of cases, the reason being young inexperienced mothers land up in the hands of traditional birth attendants and mostly deliver outside health facility due to lack of education regarding health care, antenatal visits and delivery in well-equipped medical facilities. They are unfamiliar with the process of labour, its length and complications hence undergo trials in various hands before reaching the health facility. ${ }^{16}$ Shamshad et al also reported low parity $(63 \%)$ to be significantly associated with sepsis. ${ }^{14}$ Kaur et al also reported primigravidae to be significant. ${ }^{17}$ Bako in Nigeria 18 too showed primi to be a risk factor. ${ }^{18}$ Pradhan et al in Nepal also found primigravida to be associated with increased puerperal sepsis. ${ }^{19}$

Authors found maximum number of cases $(78.4 \%)$ to be tea garden workers with homemakers being second most common accounting for $14 \%$ of cases. This is evident from the fact that most of these daily wage workers are unable to afford the cost of health facilities. For many women poverty combines with cultural constraints that build a social wall around them where health care facilities and personnel cannot reach. ${ }^{16}$ Many consider birth to be a physiological process hence prefers a home delivery where the eldest member conducts and controls the delivery. This is also reported in study conducted by Khaskheli et al in Pakistan. ${ }^{12}$ Other studies done by Shamshad et al and Tamboli et al also showed low socioeconomic status to be significant. ${ }^{14,15}$

Membranes were absent in 32 cases. Absent membranes usually signify increased chance of ascending infection from the vagina to the uterine cavity. This was also seen in studies conducted by Khaskheli et al. ${ }^{12}$ Home delivery is related to the triad of poverty, illiteracy and social constraints. Traditional birth attendants do not practice aseptic measures like hand washing and antiseptic delivery techniques. ${ }^{12}$ Shamshad et al showed up to $50 \%$ of puerperal sepsis cases are delivered by untrained attendants. ${ }^{14}$ Meharun Nissa et al showed $74 \%$ of puerperal sepsis patients to be either mismanaged or delivered by untrained persons. ${ }^{12}$ Tamboli et al showed approximately $31 \%$ of cases in home. ${ }^{15}$

Most common cause of death was septicemia. On calculating the significance of various factors involved it was seen that young age $<20$ years $(\mathrm{p}<0.001)$, primiparity $(p<0.005)$, tea garden workers $(p<0.014)$, unbooked cases $(\mathrm{p}<0.001)$, inadequate iron supplements intake $(\mathrm{p}<0.14)$, late presentations >3days ( 0.001$)$, absent membranes ( $\mathrm{p} 0.001$ ), intrauterine fetal demise ( $\mathrm{p}$ $0.001)$, caesarean section $(\mathrm{p}<0.05)$, home delivery $(\mathrm{p}<$ $0.05)$, delivery by untrained birth attendant ( $\mathrm{p}<0.001)$ and to have an organism isolated by blood culture/high vaginal swab (p 0.008) to be significant factors associated with mortality. Mortality rates in other studies were as follows: Shamshad et al showed $14.2 \%$, Meharun Nissa showed $8.5 \% .^{12,14}$ The higher mortality rate in present study could be attributed to the late presentation of many cases in which the disease process has already crossed the point of no return.

In the study Kleibsiella pneumoniae was the most common organism isolated in high vaginal swab. However, the high prevalence of CONS could be explained due to a faulty blood sample collection technique as CONS is a common commensal in skin of patients. Kaur et al in her study showed Staphylococcus aureus and Escherichia coli to be the two most common organisms isolated accounting for $36 \%$ and $29.8 \%$ of cases. ${ }^{17}$ Tamboli et al isolated Kleibsiella aerogenes and Escherichia coli to be the most common organisms in his study. ${ }^{15}$ Venugopal et al in his study isolated Escherichia coli to be the most common organism. ${ }^{20}$ In Sudan a study done by Mohd Issa et al showed Staphylococcus aureus, Staphylococcus epidermis and Clostridium perfringes to be the most common organisms. ${ }^{21}$ Salma Ahmed et al in Bangladesh isolated Escherichia coli and Escherichia fecalis to be the most common organism. Shafgufta et al in Aligarh isolated group B Streptococcus to be the most common organism followed by Escherichia coli. ${ }^{22,23}$ In present study Staphylococcus aureus was isolated in 1 case and Escherichia coli in $6 \%$ of cases. This could be explained based on regional variation of causative microorganisms.

In the study no, specific pattern could be concluded regarding what antibiotics work best for the sepsis. Hence it is best to start with empirical antibiotics after sending for a high vaginal swab/blood culture and then change the antibiotic based on culture sensitivity reports. This was also supported by Mohd Issa et al who concluded saying treatment based on cultures remains the only solution to reduce maternal morbidity. ${ }^{21}$ The study is not large enough and has encompassed a diverse group of patients belonging to various strata in a short time frame of one year and was carried out within the limits of the laboratory, so it is very difficult for one to draw a definite black and white conclusion.

The merits of the study are it gives a glance at the important factors responsible for causing puerperal sepsis in the modern era. Being performed at a tertiary institute with a wide case load from a wide referral base gives us a bird eye's view of the magnitude of the disease.

\section{CONCLUSION}

In conclusion puerperal sepsis is still a burning issue in the North eastern states of India. The principles of management include proper antenatal care, adhering to proper asepsis techniques during delivery and appropriate clinical diagnosis and laboratory tests and use of sensitive antimicrobials.

\section{Recommendations}

Among the important predisposing factors, a special mention is to be given regarding some important 
preventive aspects. As already seen anemia, teenage pregnancies, unbooked cases, improper antenatal care and prophylactic measures like consumption of iron and folic acid tablets, home delivery by untrained birth attendants and late presentation to the health care centre are important predisposing factors for puerperal sepsis. Hence there should be increased awareness camps and proper strengthening of health care facilities at grass root level. More important would be upliftment of "At risk group" of tea garden workers who account for $78.4 \%$ of cases.

\section{ACKNOWLEDGMENTS}

The authors wish to thank the Medical superintendent of Assam Medical College and hospital,Dibrugarh for his permission to do the study. The author also expresses gratitude to Miss Kalyani Vamsy Bassetty and Dr. Keerthy Chandra Bassetty for their patience and timely help in analysis of data.

Funding: No funding sources

Conflict of interest: None declared

Ethical approval: The study was approved by the Institutional Ethics Committee

\section{REFERENCES}

1. Hyakakawa $\mathrm{S}$, Komine-Aizawa $\mathrm{S}$, Naganawa $\mathrm{S}$, Shimuzu K, Nemoto N. The death of Izanami, an ancient Japanese goddess: an early report of a case of puerperal fever. Medical Hypoth. 2006; 67(4):965-8.

2. Adriaanse AH, Pel M, Bleker OP. Semmelweis: the combat against puerperal fever. Eur J Obstet Gynecol Reproduc Biol. 2000;90(2):153-8.

3. Ricci JV. The genealogy of gynaecology: history of the development of gynaecology throughout the ages, 2000 BC-1800 AD. Blakiston; 1950.

4. De Costa CM. The contagiousness of childbed fever: a short history of puerperal sepsis and its treatment. Medi J Aus. 2002; 177(11/12):668-72.

5. Khan KS, Wojdyla D, Say L, Gülmezoglu AM, Van Look PF. WHO analysis of causes of maternal death: a systematic review. The Lancet. 2006;367 (9516):106674.

6. Killian CA, Graffunder EM, Vinciguerra TJ, Venezia RA. Infect Control Hosp Epidemicol. 2001;22(10): 6137.

7. Madhudas C, Khurshid F, Sirichand P. Maternal morbidity and mortality associated with puerperal sepsis. JLUMHS. 2011;10(03):121.

8. World Health Organization. Women and health: today's evidence tomorrow's agenda. World Health Organization; 2009.

9. Fernandez-Perez ER, Salman S, Pendem S, Farmer JC. Sepsis during pregnancy. Critical Care Medi. 2005;33(10):S286-93
10. Al-Ostad G, Kezouh A, Spence AR, Abenhaim HA. Incidence and risk factors of sepsis mortality in labor, delivery and after birth: Population-based study in the USA. J Obstet Gynaecol Res. 2015;41(8):1201-6

11. Rocca CH, Puri M, Dulal B, Bajracharya L, Harper CC, Blum M, Henderson JT. Unsafe abortion after legalisation in Nepal: a cross-sectional study of women presenting to hospitals. BJOG: Int J Obstet Gynaecol. 2013;120(9):1075-84.

12. Khaskheli MN, Baloch S, Sheeba A. Risk factors and complications of puerperal sepsis at a tertiary healthcare centre. Pakistan J Medi Sci. 2013;29(4):972.

13. Singer M, Deutschman CS, Seymour CW, ShankarHari M, Annane D, Bauer M, Bellomo R, Bernard GR, Chiche JD, Coopersmith CM, Hotchkiss RS. The third international consensus definitions for sepsis and septic shock (sepsis-3). Jama. 2016;315(8):801-10.

14. Shamshad SS, Rauf B. Puerperal sepsis-still a major threat for parturient. J Ayub Med Coll Abbottabad. 2010;22(3):18-20.

15. Tamboli SS, Tamboli SB, Shrikhande S. Puerperal sepsis: predominant organisms and their antibiotic sensitivity pattern. Int $\mathbf{J}$ Reprod Contracep Obstet Gynecol. 2017;5(3):762-5.

16. Maharaj D. Puerperal pyrexia: a review. Part I. Obstet Gynecol Survey. 2007;62(6):393-9.

17. Kaur T, Mor S, Puri M, Sood R, Nath J. A study of predisposing factors and microbial flora in puerperal sepsis. Int J Reprod Contracep Obstet Gynecol. 2017;5(9):3133-6.

18. Dare FO, Bako AU, Ezechi OC. Puerperal sepsis: a preventable post-partum complication. Trop Doctor. 1998;28(2):92-5.

19. Pradhan B, Duwal SS, Singh A, Bhandary S, RC L, Shrestha R. Puerperal Sepsis and its Cause in Patan Hospital. Nepal J Obstet Gynaecol. 2015;10(1):33-5.

20. Venugopal MS, Bhaskaran CS. Puerperal and postabortal sepsis (a bacteriological study). J Obstet Gynaecol India. 1968;18 (1):70.

21. Ahmed MI, Alsammani MA. Puerperal sepsis in a rural hospital in Sudan. Materia socio-Medica. 2013; 25(1):19.

22. Ahmed S, Kawaguchiya M, Ghosh S, Paul SK, Urushibara N, Mahmud C, et al. Drug resistance and molecular epidemiology of aerobic bacteria isolated from puerperal infections in Bangladesh. Microbial Drug Resistance. 2015;21(3):297-306.

23. Shagufta Qadri. Microbial Profile in Females with Puerperal Sepsis: A Major Threat to Women s Health: Study at a Tertiary Health Care Centre. Int J Curr Microbiol App Sci. 2015;1:248-55.

Cite this article as: Bassetty $\mathrm{KC}$, Ahmed RD, Saikia L. Clinicopathological study of puerperal sepsis including microbiological profile: at a tertiary health care centre. Int J Reprod Contracept Obstet Gynecol 2018;7:3268-74. 